\title{
Uutta tutkimustietoa avomaavihanneksia vioittavista taudeista
}

\author{
Juha Tuomola $^{1)}$, Hao-Xi Li $^{1)}$, Hanna Avikainen ${ }^{2}$, Anne Piirainen ${ }^{2)}$ ja Minna Pirhonen ${ }^{1)}$. \\ ${ }^{1)}$ Maataloustieteiden laitos, PL 27,00014 Helsingin yliopisto, etunimi.sukunimi@ helsinki.fi \\ $\left.{ }^{2}\right)$ Helsingin yliopisto, Ruralia-instituutti, Lönnrotinkatu7 50100, Mikkeli, etunimi.sukunimi@helsinki.fi
}

\section{Tiivistelmä}

Viime vuosina bakteeritaudit ovat lisääntyneet Etelä-Savon vihannesviljelmillä ongelmallisten sääolosuhteiden vaikutuksesta. Jäävuorisalaatilla on havaittu enenevässä määrin bakteerien aiheuttamaa laikku- ja mätätautia, joka erityisesti lämpiminä kesinä on paikoitellen tuhonnut suuria osia sadosta. VihTa-hankkeessa kyseisen taudin aiheuttajaksi määritettiin morfologisten, biokemiallisten ja DNAsekvensointiin perustuvien menetelmien avulla Pseudomonas cichorii (Swingle) Stapp -niminen bakteeri. Alkuvuodesta 2011 Kasvinsuojeluseuran sanastojaosto ehdotti hankkeen tutkimustulosten perusteella taudin viralliseksi nimeksi salaatinpiilomätää. Piilomätätaudin torjuntatoimien kehittämiseksi selvitettiin VihTa-hankkeessa tarkemmin DNA-tekniikoiden sekä fylogeneettisten analyysien avulla P. cichorii -bakteerin monimuotoisuutta ja leviämistä pellolle. Tutkimuksissa selvisi Etelä-Savosta eristettyjen $P$. cichorii -bakteerien jakaantuvan kahteen toisistaan selkeästi poikkeavaan alaryhmään. Bakteeria ei alustavissa tutkimuksissa ole löydetty salaatinsiemenistä, kasvihuoneessa kasvatetuista nuorista taimista tai avomaalla käytettävästä kasteluvedestä. Sen sijaan patogeeni onnistuttiin eristämään talven jälkeen peltomaasta sekä siihen muokatusta salaattijätteestä. Tutkimuksen perusteella suositeltavina piilomätätaudin hallintakeinoina Suomessa voidaan pitää vuoroviljelyä, infektoituneen salaattijätteen poiskeräämistä ja hyvän viljelyhygienian noudattamista.

Pahkahome on entuudestaan tunnettu monien viljelykasvien vakava kasvinsuojeluongelma. Taudin on Suomessa katsottu olevan isäntäkasvista riippumatta yksinomaan Sclerotinia sclerotiorum (Lib.) de Bary -sienen aiheuttama. Avomaavihanneksia infektoivat kirjallisuuden mukaan myös $S$. minor Jagger ja S. subarctica nom. prov. (Sclerotinia species 1) -nimiset lajit. Kummastakaan ei ole aiempia havaintoja Suomesta. VihTa-hankkeessa kartoitettiin pahkahomeen aiheuttamia satotappioita Etelä-Savon vihannesviljelmillä sekä määritettiin tarkemmin morfologisten ja DNA-tekniikkaan perustuvien menetelmin avulla vihanneksille pahkahometta aiheuttavat lajit. Lisäksi hankkeessa selvitettiin mikrosateliitti-DNA-menetelmien avulla tarkemmin pahkahomeiden lajinsisäistä monimuotoisuutta. Tutkimuksessa Etelä-Savon vihannesviljelmillä havaituista pahkahomeinfektioista tunnistettiin $S$. sclerotiorum lajin lisäksi myös $S$. subarctica nom. prov. -laji. Aiemmin S. subarctica nom. prov. on tavattu vain luonnonkasveilla Norjassa ja Iso-Britanniassa, sekä avomaavihanneksilta Yhdysvalloissa, Alaskan osavaltiossa. Etelä-Savosta S. subarctica nov. prov. -sieniä eristettiin parsakaalin, kurpitsan, jäävuorisalaatin sekä roomansalaatin pahkahomeinfektioista. Patogeenisyyskokeissa $S$. subarctica nov. prov. aiheutti jäävuorisalaatille täysin samankaltaisia taudinoireita kuin S. sclerotiorum. Molempien pahkahomelajien populaatiot Etelä-Savossa osoittautuivat mikrosatelliitti-DNA-tutkimuksen perusteella hyvin heterogeenisiksi.

\section{Asiasanat}

salaatinpiilomätä, Pseudomonas cichorii, pahkahome, Sclerotinia subarctica nov. prov., Sclerotinia sclerotiorum 


\section{Johdanto}

Viime vuosina bakteeritaudit ovat lisääntyneet Etelä-Savon vihannesviljelmillä ongelmallisten sääolosuhteiden vaikutuksesta. Bakteeritautien ohella pahkahome on tunnetusti merkittävä taudinaiheuttaja koko vihannestuotantosektorilla. Tautien taloudellinen merkitys on ammattiviljelijöille suuri, sillä sadonmenetys korjuuvaiheessa voi lajista ja lajikkeesta riippuen nousta jopa $50 \%$ :iin. Eteläsavolaisten vihannesviljelijöiden aloitteesta edellä mainittujen tautiongelmien tutkimusta toteutettiin Maa- ja metsätalousministeriön rahoittamassa, Vihannestilojen kannattavuuden kehittäminen tautien ja lannoituksen hallinnalla (VihTa) -hankkeessa.

Viime vuosina Etelä-Savon jäävuorisalaattipelloilla on havaittu enenevässä määrin ikävää bakteerien aiheuttamaa laikku- ja mätätautia. Erityisesti lämpiminä kesinä tauti on paikoitellen tuhonnut suuria osia sadosta. Tyypillisesti taudin oireet ilmenevät jäävuorisalaatilla kerän sisälehdissä ensin pieninä tummina laikkuina, jotka myöhemmin laajenevat ja alkavat mädäntyä. Tavallisesti kerän ulkolehdet säilyvät infektiossa vahingoittumattomina, joskin vuonna 2011 oireita oli havaittavissa myös kerän ulkolehdissä. Tauti on muodostunut tuotannon kannalta erityisen hankalaksi, koska sitä ei salaatin korjuuvaiheessa pystytä tehokkaasti havaitsemaan. Oireet muistuttavat erityisesti Pseudomonas cichorii (Swingle) Stapp -bakteerin aiheuttamaa "varnish spot" -nimistä tautia (Grocan ym. 1977), joka 1970-luvulla muodostui nopeassa tahdissa jäävuorisalaatin vakavaksi kasvinsuojeluongelmaksi Yhdysvalloissa, Japanissa ja Italiassa. Myös muiden bakteerien, erityisesti muiden fluoresoivien pseudomonasten on huomattu aiheuttavat jäävuorisalaatille samankaltaisia oireita. Kankila (1998) havaitsi edellä mainitun kaltaisia bakteeritautiongelmia Kaakkois-Pirkanmaan jäävuorisalaattipelloilla jo 1990luvun lopulla. Tutkijat onnistuivat eristämään tällöin salaatista muun muassa $P$. cichorii -bakteereja, mutta patogeenisyyskokeiden puuttuessa jäivät taudin syy-seuraussuhteet tällöin tarkemmin selvittämättä. VihTa-hankkeen havaintojen tapaan myös Kaakkois-Pirkanmaalla taudin huomattiin olevan vakavampi ongelma nimenomaan lämpiminä kasvukausina.

Maailmanlaajuisesti merkittävää salaatin "varnish spot" -tautia pidetään sekä siemen- että maalevintäisenä. Kasvustossa bakteeri leviää sadeveden aiheuttamissa roiskeissa ja kasvihuoneisiin patogeenin on huomattu pääsevän kasteluveden mukana. Koska $P$. cichorii -bakteerin aiheuttamat taudinoireet ilmenevät tyypillisesti vasta korjuukypsillä kasveilla, täytyy taudin torjunnan perustua ennen kaikkea epidemioiden ennaltaehkäisemiseen. Ennaltaehkäiseviä $P$. cichorii -infektioiden torjuntatoimenpiteinä pidetään terveen kylvösiemenen käyttöä, viljelykiertoa, infektoituneen salaattijätteen poiskeräämistä, liiallisen kastelun välttämistä sekä yleisesti hyvän viljelyhygienian noudattamista.

Pahkahome aiheuttaa maailmanlaajuisesti vakavia tuhoja lukuisille eri viljelykasveille. Suomessa taudin on katsottu olevan isäntäkasvista riippumatta yksinomaan Sclerotinia sclerotiorum (Lib.) de Bary -sienen aiheuttama. Jäävuorisalaattia infektoi kuitenkin kirjallisuuden mukaan myös $S$. minor Jagger -niminen pahkahomesieni. S. minor -lajista on havaintoja Etelä- ja Keski-Euroopasta, Etelä- ja Pohjois-Amerikasta, Aasiasta, Afrikasta ja Australiasta, mutta havaintoja Suomesta ei ole kirjattu. Lisäksi avomaavihanneksille pahkahometta aiheuttaa vasta hiljattain tieteelle kuvattu S. subarctica nov. prov. (Sclerotinia species 1) -niminen sieni. Toistaiseksi S. subarctica nov. prov. -lajin on havaittu aiheuttavan pahkahometta vihanneksille vain Yhdysvalloissa, Alaskan osavaltiossa. Taudinaiheuttaja on eristetty myös luonnonkasveilta Norjasta ja Iso-Britanniasta. Sclerotinia-suvusta muita Suomalaisittain merkittäviä patogeenejä ovat apilamätää aiheuttava S. trifoliorum Erikss., sekä nurmikasveja vahingoittava pohjanpahkasieni $S$. borealis Bubak et Vleugel.

Pahkahomesienten elinkiertoon kuuluvat tiiviit rihmastopahkat (sklerootiot), joiden avulla se säilyy maassa useita vuosia. Sopivissa olosuhteissa pahkat tuottavat maljamaisia itiöemiä (apoteekio), joista vapautuvat koteloitiöt leviävät pitkiä matkoja. Sopivan isäntäkasvin kasvaessa lähellä saattaa maassa itävä pahka tuottaa itiöemien sijaan vain pelkkää sienirihmastoa. S. minor -lajin on todettu tuottavan itiöemiä ja itiöitä vain harvoin, kun taas S. sclerotiorum -lajin katsotaan tyypillisesti suosivan ilmalevintää koteloitiöiden avulla. Tosin viileissä ilmasto-olosuhteissa maalevinnällä katsotaan olevan enemmän merkitystä myös $S$. sclerotiorum -lajin kohdalla. Koteloitiöt ovat pahkahomeen suvullisia lisääntymisrakenteita, joten niiden muodostuminen edellyttää pariutumista. S. sclerotiorum lajia pidetään homotallisena sienenä, mikä tarkoittaa että lajilla on vain yhdenlaista pariutumistyyppiä edustavia sienirihmoja, joiden välillä suvullinen lisääntyminen voi tapahtua. Toisin sanoen sieniyksilö ei välttämättä tarvitse toista osapuolta pariutumiseen ja suvulliseen lisääntymiseen. Populaation geneettistä monimuotoisuutta tutkimalla voidaan saada lisätietoa yksilöiden välisen pariutumisen toden- 
näköisyydestä ja sitä kautta viitteitä myös siitä, tapahtuuko paikallisessa pahkapopulaatiossa leviämistä suvullisten itiöiden avulla.

Jäävuorisalaatilla ilmenevän bakteeritaudin osalta tämän tutkimuksen tavoite oli selvittää taudin etiologia Kochin postulaateissa määritettyjen periaatteiden mukaisesti, morfologiaan, biokemiallisiin ominaisuuksiin ja DNA-sekvensointiin perustuvien menetelmien avulla. Lisätavoitteena oli selvittää DNA-sekvensoinnin ja fylogeneettisten analyysien perusteella taudinaiheuttajaksi määritetyn patogeenin monimuotoisuutta sekä talvehtimista peltomaassa. Pahkahomeen osalta tämän tutkimuksen tavoite oli määrittää morfologiaan, DNA-tekniikkaan ja sekvensointiin perustuvien menetelmien avulla vihanneksia Etelä-Savossa infektoivat pahkahomelajit. Lisäksi osatavoitteena oli saada mikrosateliittiDNA-menetelmien avulla lisätietoa pahkahomepopulaatioiden monimuotoisuudesta Etelä-Savossa.

\section{Aineisto ja menetelmät}

\section{Bakteerien eristäminen, tunnistaminen ja patogeenisyyskokeet}

Rapeakeräsalaatilla esiintyvän bakteeritaudin etiologia selvitettiin 22 tautinäytteestä, jotka olivat kerätty vuosien 2009-2011 aikana neljältä eri vihannesviljelytilalta Etelä-Savosta. Kaikki morfologialtaan erityyliset bakteeripesäkkeet siirrostettiin puhdasviljelmiksi, joista Pseudomonas-suvun lajit tunnistettiin alustavasti niiden fluoresoivan pigmentin muodostuskyvyn perusteella. Pseudomonakset tunnistettiin tarkemmin biokemiallisia ominaisuuksia mittaavan LOPAT-koesarjan perusteella sekä sekvensoimalla osa bakteerien 16S rRNA-geenistä. Patogeenisyyskokeissa näytteistä eristettyjen bakteerien taudinaiheuttamiskyky testattiin infektoimalla niillä terveitä salaatinlehtiä. Oireiden ilmaannuttua eristettiin oirekohdista bakteereja, jotka tunnistettiin fluoresoimisreaktion ja LOPAT-koesarjan avulla. Tarkemmat tiedot tutkimukseen sovelletuista menetelmistä ja koejärjestelyistä on esitelty Tuomolan (2011) maisterintutkielmassa.

\section{Taudinaiheuttajabakteerien monimuotoisuus ja talvehtiminen peltomaassa}

Taudinaiheuttajaksi määritetyn bakteerin monimuotoisuutta Etelä-Savossa analysoitiin kaikkien edellä mainittujen lajimääritykseen käytettyjen menetelmien osalta, sekä sekvensoimalla osa taudinaiheuttajien hypersensitiivisyys ja patogeenisyysalueen $(h r p) h r c R S T$-geeneistä. Sekvensointiin ja fylogeneettisiin analyyseihin valittiin 20 taudinaiheuttajaksi tunnistettua bakteeri-isolaattia, jotka olivat pääsääntöisin eristetty eri tautinäytteistä. Lisäksi fylogeneettisiin analyyseihin haettiin NCBI:n sekvenssitietokantaan (http://www.ncbi.nlm.nih.gov/) tallennettuja kansainvälisiä taudinaiheuttajabakteerin hrpalueen sekvenssejä. Sovelletut menetelmät $h r c R S T$-geenien monistamiseksi, sekä fylogeneettisten analyysien toteuttamiseksi on esitelty Tuomolan (2011) maisterintutkielmassa.

Taudinaiheuttajaksi määritetyn bakteerin talvehtimista peltomaassa tutkittiin keväällä 2011 kerätyistä kymmenestä peltomaanäytteestä, jotka kaikki sisälsivät myös maatumatonta salaattijätettä edelliseltä kasvukaudelta. Kaikista näytteistä eristettiin DNA:ta MoBio Laboratories Inc. PowerMax ${ }^{\circledR}$ DNA Isolation Kit -valmispakkauksen avulla valmistajan ohjeiden mukaisesti. Kahdeksasta maanäytteestä eristettiin bakteereja pintahajotusmenetelmällä suoraan PCSM- ja PCM-1-selektiivialustoille (Jones ym. 1990, Uematsu ym. 1982). Maljoja inkuboitiin $+28{ }^{\circ} \mathrm{C}:$ ssa seitsemän vuorokautta, minkä jälkeen maljalle rikastuneesta bakteerisekakasvustosta eristettiin DNA:ta Qiagen DNeasy Blood \& Tissue Kit -valmispakkauksen avulla. Eristettyä DNA:ta monistettiin PCR:ssä Verbaendertin (2006) kuvaamilla F2- ja R1-alukkeilla, jotka spesifisesti monistavat patogeenin $h r p$-alueelta noin 230 nukleotidin mittaista DNA-fragmenttia. Monistuneiden fragmenttien koko ja silmämääräinen kvantifiointi suoritettiin geelielektroforeesin avulla vertaamalla näytteitä ajossa mukana olleeseen kokostandardiin sekä useisiin tunnettuihin vertailukantoihin. Koe suoritettiin kolmena toistona kaikille näytteille. Silmin nähtävä oikeankokoinen DNA-fragmentti tulkittiin positiiviseksi. Kolmen selkeän positiivisen tuloksen jälkeen fragmentti eristettiin ja sekvensoitiin tarkemman tunnistustuloksen saamiseksi. Sekvensseistä muodostettiin fylogeneettinen sukupuu samaan tapaan kuin $h r c R S T$-kokeessa. Lisäksi fylogeneettisiin analyyseihin liitettiin sekvenssitietoja $h r c R S T$-kokeesta sekä NCBI:n sekvenssitietokannasta.

\section{Pahkahomelajien tunnistaminen ja monimuotoisuus Etelä-Savossa}

Sienet eristettiin pintasteriloiduista vihannesnäytteistä vuosien 2009-2011 aikana. Puhdasviljelmiä kasvatettiin peruna-dekstroosi-agarilla (PDA), joista ne tunnistettiin alustavasti pahkahomeiksi morfo- 
logisten ominaisuuksien perusteella. Tarkempi lajinmääritys tehtiin sekvensoimalla osa sienten ITS-2 (internal transcribed spacer) alueesta ja vertaamalla sitä BLAST-algoritmin avulla NCBI:n verkkosivuilla (http://www.ncbi.nlm.nih.gov/BLAST) kansainvälisiin sekvenssitietokantojen vastaaviin sekvensseihin, sekä Holst-Jensenin ym. (1998) julkaisemaan Sclerotiniaceae-heimon ITSsekvenssiaineistoon. Edelleen eri pahkahomelajeja pyrittiin erottamaan toisistaan tutkimalla PCRpohjaisten menetelmien avulla sisältääkö niiden $28 \mathrm{~S}$ rRNA-geeni (LSU) ryhmä 1 -nimisen intronin (Group 1 intron). Holst-Jensenin (1998) mukaan S. sclerotiorum -lajin 28S rRNA-geeni sisältää noin 300 nukleotidin mittaisen ryhmä 1 intronin, kun taas $S$. subarctica nov. prov. ja $S$. minor -lajeilta se kokonaan puuttuu. Tarkemmat tiedot tutkimukseen sovelletuista menetelmistä on esitelty Li' in (2011) maisterintutkielmassa.

Pahkahomeisolaattien monimuotoisuutta analysoitiin mikrosatelliitti-DNA-menetelmien perusteella. Tutkimuksiin käytettiin Sirjusinghin \& Kohnin (2001) kuvaamia mikrosatelliitteja 7-2, 13-2, 55-4, 110-4, sekä Wintonin ym. (2007) kuvaamia satelliitteja 1,3, 5 ja 7. PCR-menetelmät toteutettiin Sirjusinghin \& Kohnin (2001) ohjeiden mukaisesti. Fragmenttianalyysi suoritettiin Helsingin yliopiston, Biotekniikan instituutissa ja analyysin tulokset tarkistettiin Peak Scanner ${ }^{\mathrm{TM}}$ v1.0 -ohjelmalla. Populaatiossa tapahtuvan satunnaispariutumisen todennäköisyyttä arvioitiin Multilocus 1.3b -ohjelmalla.

\section{Tulokset ja tulosten tarkastelu}

\section{Bakteeritautin etiologia}

Morfologisten ominaisuuksien, LOPAT-kokeiden, 16S rRNA-geenin sekvensointitulosten ja patogeenisyyskokeiden tulosten perusteella jäävuorisalaatilla esiintyvän laikku- ja mätätaudin ensisijaiseksi taudinaiheuttajaksi määritettiin $P$. cichorii -bakteeri. Kasvinsuojeluseuran sanastojaosto nimesi taudin hankkeen tutkimustulosten perusteella salaatinpiilomädäksi. Myös muut näytteistä eristetyt pseudomonakset aiheuttivat patogeenisyyskokeissa oireita salaatille. Nämä oireet olivat kuitenkin lähtökohtaisesti erilaisia kuin piilomätäinfektioissa, eikä yleisesti niin vakavia kuin $P$. cichorii -bakteerin aiheuttamat oireet. Todennäköisesti muut pseudomonakset esiintyvät pitkälle edenneissä salaatinpiilomätäinfektioissa sekundaarisina patogeeneinä.

\section{P. cichorii -bakteerin monimuotoisuus ja talvehtiminen Etelä-Savossa}

Morfologisten ominaisuuksien ja hrcRST-sekvenssien perusteella $P$. cichorii -bakteerit jakaantuivat kahteen toisistaan selvästi poikkeavaan ryhmään PC1 ja PC2 (Kuva 1). Osa sekvenssitietokannan $P$. cichorii - bakteereista muodostivat fylogeneettisissa analyyseissä myös kolmannen $P$. cichorii alaryhmän PC3. Määritetyt ryhmät vastaavat monelta osin hiljattain Belgiassa määritettyjä $P$. cichorii -alaryhmiä (Cottyn ym. 2009).

Maanäytteistä onnistuttiin eristämään $P$. cichorii -bakteerin $h r c$-alueen DNA:ta sekä suoraan maasta että selektiivialustoilla rikastetussa bakteerisekaviljelmistä. Sekvensseistä muodostetussa fylogeneettisessa sukupuussa oli selkeästi havaittavissa maanäytteistä monistuneiden sekvenssien yhdenmukaisuus $P$. cichorii -vertailukantojen vastaaviin sekvensseihin. Koska $P$. cichorii -bakteeri pystyi talven jälkeen rikastumaan kokeissa käytetyillä selektiivialustoilla, voidaan sen maassa talvehtivaa populaatiota pitää hyvinkin elinvoimaisena. Maanäytteiden $P$. cichorii -bakteerit olivat analysoidun sekvenssialueen perusteella täysin identtisiä niiden $P$. cichorii -bakteerien kanssa, jotka olivat eristetty samaisilta pelloilta edellisenä kesänä (Kuva 1).

\section{Pahkahomelajit}

Suurin osa vihanneksilta eristetyistä pahkahomeisolaateista tunnistettiin morfologian, ITS-2 alueen sekvenssien ja ryhmä I intronin havaitsemiseen perustuvin menetelmin S. sclerotiorum -lajiksi. Yllättäen osa kannoista tunnistettiin edellä mainittujen menetelmien perusteella $S$. subarctica nov. prov. lajiksi. Molempia lajeja löydettiin samoilta vihannespelloilla. Aiemmin S. subarctica nov. prov. sientä on tavattu vain luonnonkasveilla Norjassa ja Iso-Britanniassa, sekä avomaavihanneksilla Yhdysvalloissa, Alaskan osavaltiossa (Clarkson ym. 2010, Holst-Jensen ym. 1998, Winton ym. 2006, Winton ym. 2007). Etelä-Savossa S. subarctica nov. prov. -sieniä eristettiin parsakaalista, kurpitsasta, jäävuorisalaatista sekä roomansalaatista. Näistä parsakaalia voidaan pitää uutena $S$. subarctica nov. prov. -lajin isäntäkasvina. Lajin patogeenisyys testattiin jäävuorisalaatilla, jolle se aiheutti täysin samankaltaisia pahkahomeoireita kuin S. sclerotiorum (Kuva 2). Jäävuorisalaatin osalta myös Kochin 
postulaatit täytettiin, kun taudinaiheuttaja uudelleen eristettiin infektoiduista salaateista ja tunnistettiin rihmaston yhteneväisyyskokeen (MCG - mycelial compatibily group) avulla. Morfologian perusteella edellä mainitut lajit muistuttavat hyvin paljon toisiaan, joskin pahkojen koossa, niiden määrässä sekä puhdasviljelmien värissä PDA:lla on havaittavissa eroja (Kuva 2). ITS-2 sekvenssien perusteella lajit ovat verrattain luotettavasti erotettavissa toisistaan ja muista Sclerotinia-suvun lajeista. Niin ikään Líin (2011) ryhmä I intronin havainnointimenetelmä osoittautui hyvin luotettavaksi ja nopeaksi menetelmäksi erottaa nämä kaksi morfologialtaan samankaltaista pahkahomelajia toisistaan.
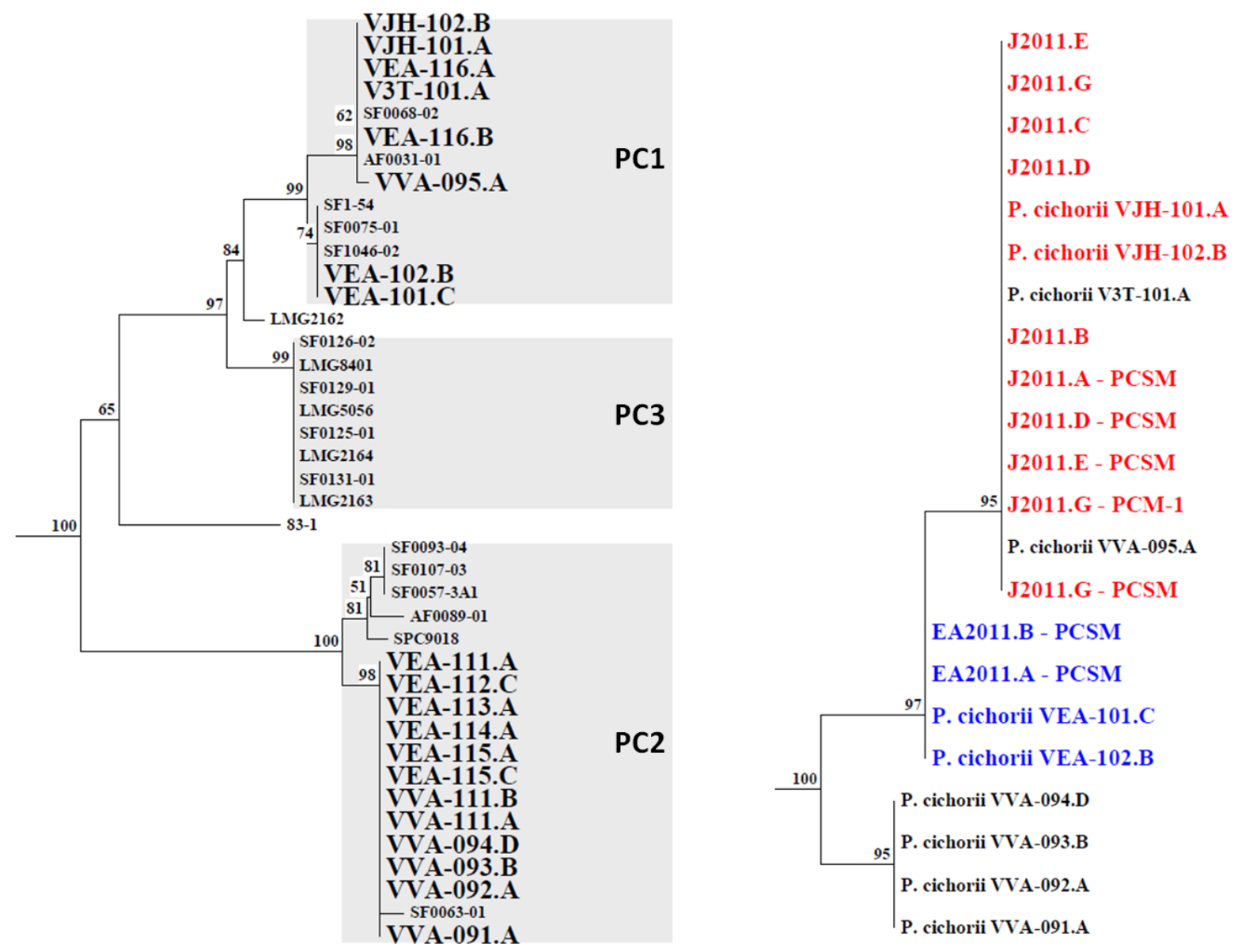

Kuva 1. Vasemmalla fenogrammi joka on muodostettu Etelä-Savosta eristettyjen sekä NCBI:n tietokannasta haettujen $P$. cichorii -bakteerien 803 nukleotidin mittaisten $h r c R S T$-sekvenssien perusteella. Kolme eri $P$. cichorii -ryhmää (PC1, PC2 ja PC3) näkyvät kuvassa tummennettuina. Etelä-Savosta eristetyt kannat ovat lihavoitu. Oikean puoleisessa kuvassa maanäytteistä muodostettu fenogrammi, joka on muodostettu Etelä-Savosta eristettyjen $P$. cichorii -bakteerien 223 nukleotidin mittaisten $h r c$-sekvenssien sekä maanäytteistä monistuneiden sekvenssien perusteella. Kuvassa punaisella on merkitty Juvalta vuonna 2010 eristettyjen $P$. cichorii -bakteerien (VJH-101.A ja VJH-102.B) $h r c$-sekvenssit, sekä samaiselta pellolta maanäytteistä vuonna 2011 (J2011.A, J2011.B, J2011.C, J2011.D, J2011.E, J2011.G) peräisin olevat sekvenssit. Sinisellä on merkitty Joroisista peräisin olevat maanäytteiden (EA2011.B ja EA2011.A) sekvenssit, sekä samalta pellolta vuonna 2010 tautisista näytteistä eristettyjen P. cichorii -bakteerien (VEA-101.C, VEA-102.B) sekvenssit. Molemmat sukupuut ovat muodostettu TREECON for Windows -ohjelmalla. Kantojen etäisyyksiä toisistaan arvioitiin Jukes \& Cantorin evoluutiomallin avulla ja puun muodostukseen käytettiin NJ-algoritmia. Tuhannen bootstrapping-toiston tukiprosentit näkyvät puun haaraumakohdissa.

\section{S. sclerotiorum ja S.subarctica -lajien monimuotoisuus.}

Pahkahomesienten monimuotoisuustutkimuksiin valittiin 23 S. sclerotiorum -isolaattia, jotka olivat kaikki kerätty vuosien 2010 ja 2011 aikana samalta pellolta, sekä kaikki 11 tutkielmassa määritettyä $S$. subarctica nov. prov. -isolaattia. Mikrosatelliitti markkerit 7-2, 13-2, 55-4, 110-4 osoittivat 
23 S. sclerotiorum -isolaatin sisältävän 13 eri genotyyppiä, kun taas $S$. subarctica nov. prov. -lajin osalta kaikki 11 isolaattia olivat markkerien $1,3,5$ ja 7 mukaan geneettisesti toisistaan poikkeavia. $S$. subarctica nov. prov. -isolaattien määrä ei enää riittänyt luotettavampiin tilastollisiin analyyseihin. Sen sijaan S. sclerotiorum -lajin monimuotoisuutta analysoitiin edelleen Multilocus 1.3b -ohjelmalla, jonka tulosten mukaan tutkitussa $S$. sclerotiorum -populaatiossa todennäköisesti tapahtuu yksilöiden välistä pariutumista $\left(\mathrm{I}_{\mathrm{A}}\right.$-arvo $\left.0,081, P=0,18\right)$. Tulokset viittaisivat suvullisten itiöiden kuuluvan osaksi lajin paikallista ekologiaa.

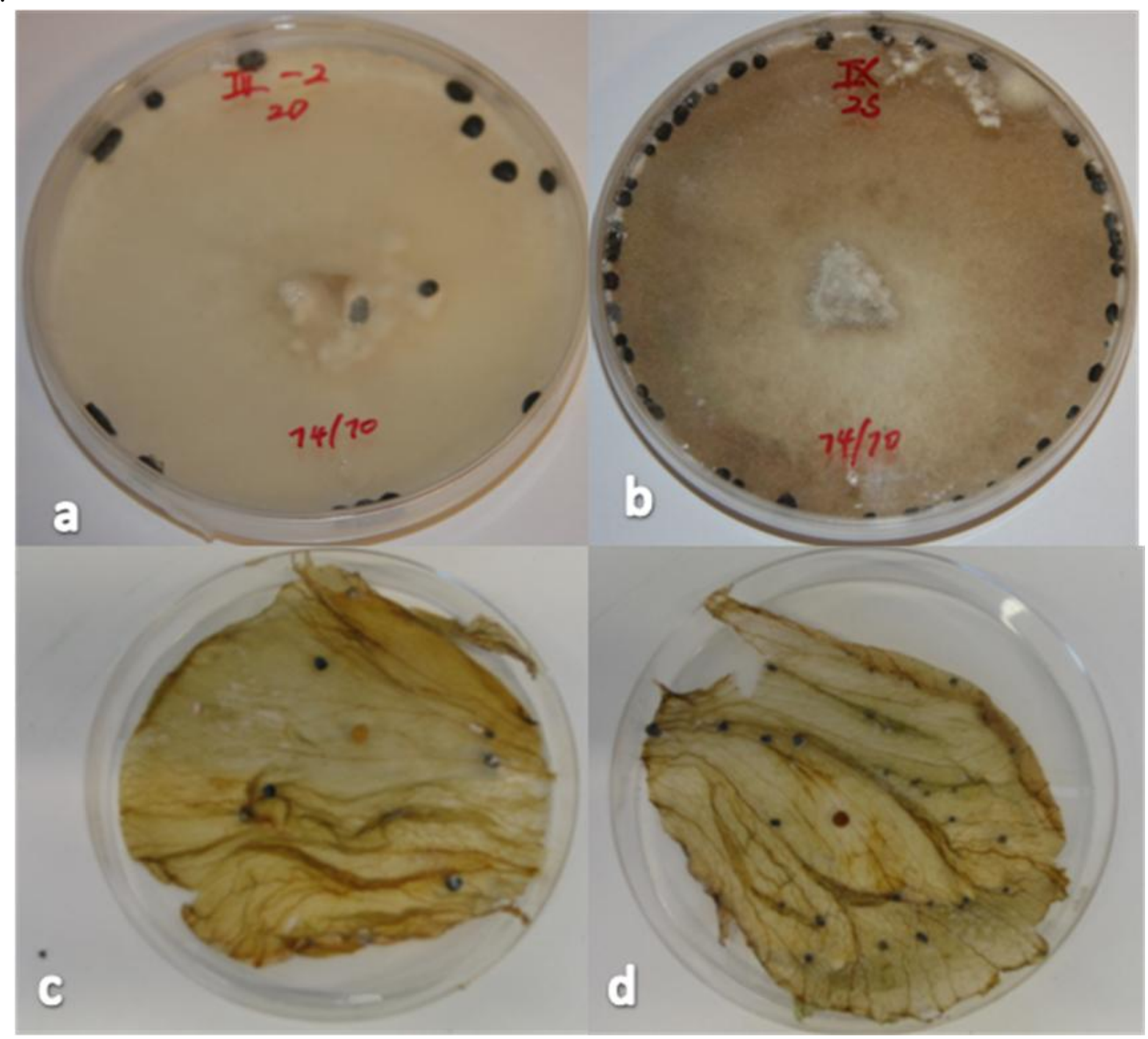

Kuva 2. S. sclerotiorum ja S. subarctica nov. prov. -lajien morfologiset erot PDA:lla, sekä sienten aiheuttamat oireet jäävuorisalaatille. S. subarctica nov. prov. (a) muodostaa S. sclerotiorum -lajiin (b) verrattuna vähemmän pahkoja, jotka kuitenkin kooltaan ovat suurempia. Lisäksi eroja voidaan havaita kasvuston värissä. Patogeenisyyskokeissa $S$. subarctica nov. prov. (c) aiheutti täysin samankaltaisia pahkahomeoireita salaatille kuin $S$. sclerotiorum $(\mathrm{d})$.

\section{Johtopäätökset}

Jäävuorisalaatilla ilmenevän salaatinpiilomätätaudin aiheuttajaksi määritettiin $P$. cichorii -bakteeri. Bakteeria ei alustavissa tutkimuksissa ole löydetty salaatinsiemenistä, kasvihuoneessa kasvatetuista nuorista taimista tai avomaalla käytettävästä kasteluvedestä. Sen sijaan patogeeni onnistuttiin eristä- 
mään talven jälkeen peltomaanäytteistä, jotka sisälsivät maahan muokattua maatumatonta salaattijätettä. Maanäytteistä eristetyt bakteerit vastaavat ominaisuuksiltaan bakteereja, joita samaisilla pellolla eristettiin salaateista edellisenä kesänä. Tutkimuksen perusteella suositeltavina piilomätätaudin hallintakeinoina Suomessa voidaan pitää vuoroviljelyä, infektoituneen salaattijätteen pois keräämistä ja hyvän viljelyhygienian noudattamista.

Pahkahometta vihanneksille Suomessa aiheuttavat sekä S. sclerotiorum että $S$. subarctica nov. prov. -lajit. Mahdollisesti sienillä on Suomessa myös muitakin yhteisiä isäntäkasveja. Molemmat lajit esiintyvät Etelä-Savossa geneettisesti hyvin monimuotoisina, mikä viittaa suvullisten koteloitiöiden olevan osa lajien paikallista ekologiaa. Jatkossa olisi tärkeää selvittää erityyppisten pahkahomerotujen virulenttisuutta eri isäntäkasveilla.

\section{Kirjallisuus}

Clarkson, J. P., Carter, H. E. \& Coventry, E. 2010. First report o Sclerotinia subarctica nov. prov. (Sclerotinia species 1) in the UK on Ranunculus acris. New Disease Reports 20: 36

Cottyn, B., Heylen, K., Heyrman, J., Vanhouteghem, K., Pauwelyn, E., Bleyaert, P., Van Vaerenbergh, J., Höfte, M., De Vos, P. \& Maes, M. 2009. Pseudomonas cichorii as the causal agent of greenhouse-grown butterhead lettuce in Flanders. Systematic and Applied Microbiology 32: 211-225.

Cottyn, B.. Baeyen, S., Pauwelyn, E., Verbaendert, I., Bleyaert, P., Höfte, M., De Vos, P. \& Maes M. 2011. Development of a real-time PCR assay for Pseudomonas cichorii and its detection in water used for irrigating greenhouse-grown lettuce. Plant Pathology 60 (3): 453-461.

Grogan, R. G., Misaghi, I. J., Kimble, K. A., Greathead, A. S., Ririe, D., Bardin, R. 1977. Varnish spot, destructive disease of lettuce in California caused by Pseudomonas cichorii. Phytopathology 67: 957-960.

Holst-Jensen, A., Vaage, M. \& Schumacher, T. 1998. An approximation to the phylogeny of Sclerotinia and related genera. Nordic Journal of Botany 18: 705-719.

Jones, J. B. 1990. Selective isolation of Pseudomonas cichorii from soil and from leaves and buds of Dendranthema grandiflora. Plant Disease 74 (4): 300-303

Kankila, J. 1998. Tervettä salaattia sateisesta Suomesta. Kasvinsuojelulehti 4: 108-110.

Li, H.-X. 2011. Identification on Sclerotinia species infecting vegetables in Etelä-Savo region, Finland. Department of Agricultural Sciences, University of Helsinki, MScPPS/Plant Pathology Master's thesis. 47 s.

Sirjusingh, C. \& Kohn, L. 2001. Characterization of microsatellites in the fungal plant pathogen, Sclerotinia sclerotiorum. Molecular Ecology Notes 1: 267-269.

Tuomola, J. 2011. Salaatinpiilomätätaudin etiologia. Maataloustieteiden laitos, Helsingin Yliopisto, Kasvintuotantotieteiden maisterin tutkielma. $107 \mathrm{~s}$.

Uematsu, T., Takatsu, A. \& Ohata, K. 1982. A medium for the selective isolation of Pseudomonas cichorii. Annals of the Phytopathological Society of Japan 48 (4): 425-432.

Vebbaendert, I. 2007. Real-Time PCR detection of Pseudomonas cichorii, the causal agent of midrib rot in lettuce. Department of Biochemistry, Physiology and Microbiology, University of Ghent, Belgium, MSc thesis. https://archive.ugent.be/retrieve/5861/thesisvolledig.pdf (9.12.2008)

Winton, L. M., Leiner, R. H. \& Krohn, A. L. 2006. Genetic diversity of Sclerotinia species from Alaskan vegetable crops. Canadian Journal of Plant Pathology 28: 426-434.

Winton, L. M., Krohn, A. L. \& Leiner, R. H. 2007. Microsatellite markers for Sclerotinia subarctica nom. prov., a new vegatable pathogen of the High North. Molecular Ecology Notes 7: 1077-1079. 